\title{
humanidades
}

Revista de la Escuela de Estudios Generales, Universidad de Costa Rica

Enero-junio, 2017 •Volumen 7, número 1 • EISSN 2215-3934•pp. 1-34

Recibido: 08-Febrero-2016 Aceptado: 02-Mayo-2016

\section{Un iconotexto liminar. Análisis iconológico de los grafiti de firma}

DOI: http://dx.doi.org/10.15517/h.v7i1.27623

\section{Juan A. González de Requena Farré}

Académico de la Universidad Austral de Chile

Correo electrónico: jagref8@gmail.com

Todos los derechos reservados. Universidad de Costa Rica. Esta revista se encuentra licenciada con Creative Commons. Reconocimiento-NoComercial-SinObraDerivada 3.0 Costa Rica.

Correo electrónico: humanidades@ucr.ac.cr / Sitio web: http://revistas.ucr.ac.cr/index.php/humanidades 


\title{
Un iconotexto liminar. Análisis iconológico de los grafiti de firma
}

\section{Resumen}

Se realiza una exégesis iconológica del grafiti de firma, basada en la propuesta de Panofsky: se exploraran sus motivos y se reconstruirán algunas tradiciones que sustentan sus modos de significación sentido, para concluir con una interpretación del trasfondo epocal y comprensión cultural que le da sentido. En este trabajo, se sostiene que el grafiti de firma constituye un tipo de icononimia o idio-grafía sin guion, en el que imagen y texto se hacen tan inseparables, como indecidible resulta el sentido de este tipo de inscripción, que oscila entre la auto-expresión agonista y la desregulación simbólica asociada al globalismo banal.

\section{A liminal iconotext. Iconological analysis of graffiti signature}

\begin{abstract}
This article aims to make a iconological exegesis of graffiti signature, based on the proposal of Panofsky: we explore its motifs, and some traditions that sustain its ways of meaning will be rebuilt, concluding with an interpretation of the epochal background and cultural understanding that give sense to it. This paper argues that graffiti signature is a type of icononimia or idio-graphy without a script, in which image and text become so inseparable, as undecidable is the meaning of such inscriptionn, ranging from agonist self-expression to symbolic deregulation associated with banal globalism.
\end{abstract}

Keywords: Graffiti, aesthetics, art theory, semiotics, culture. 
En la sobresaturada iconosfera de nuestras ciudades se ha vuelto habitual la aparición de cierto tipo de inscripciones estilizadas, normalmente designadas como grafitis; recubren no solo los muros y murallas de todo tipo de construcciones, edificios e instalaciones — públicos o privados, comerciales o habitacionales, habitados o deshabitados-, sino también el conjunto del mobiliario urbano y las superficies - internas o externas - de los vehículos del transporte público. Esta extraña profusión de imágenes, signos y símbolos gráficos genera irritación entre los propietarios de los inmuebles, malestar entre los usuarios de los espacios públicos y medios de transporte, preocupación entre las autoridades, indiferencia entre la mayoría de los peatones, fascinación comprometida entre los cultores del género, así como cierto interés reflexivo entre algunos intelectuales, científicos sociales y estudiosos del arte contemporáneo.

Las lecturas de esas inscripciones estilizadas tan pronto enfatizan la dimensión de problema social, de expresión marginal, de transgresión juvenil o de acto vandálico, como buscan en el grafiti los nuevos códigos estéticos, los lenguajes artísticos emergentes, los modos de significación implicados, las formas de agencia política, o bien los estilos y trasfondos culturales. De ese modo, la batalla cotidiana por las superficies, los estilos y la notoriedad, o la lucha institucional contra el vandalismo y por la preservación de los espacios públicos, continúan por otros medios, bajo la forma de un conflicto de las interpretaciones del grafiti.

\section{Un iconotexto sin guion}


Con frecuencia se señala que el fenómeno no es totalmente nuevo, ya que desde la antigüedad encontramos inscripciones estilizadas y mensajes gráficos anónimos (como los descubiertos en las paredes de Pompeya), del mismo modo que hallamos cierto tipo de grafiti tallado o escarbado en las sillerías de los coros de las iglesias medievales, $\mathrm{y}$, con la creciente alfabetización, se multiplican los nombres y consignas en los bancos y pupitres de las escuelas y universidades modernas (Blume, 1985).

Ciertamente, por los más diversos pasajes de las grandes ciudades de una modernidad capitalista, industrializada y concentrada urbanamente, se despliega un complejo repertorio de huellas tanto de las muchedumbres solitarias y los individuos anónimos, cuanto de los movimientos sociales y de las formaciones políticas; todo tipo de lemas, apodos, insultos, imprecaciones, sugerencias, propuestas, recados o recordatorios, irrumpe masivamente en los espacios liminales y en las fronteras socioeconómicas, en las barriadas y en los guetos, en los lugares de paso y en los callejones sin salida, en los grandes monumentos y en los habitáculos escatológicos más infames.

No obstante, en la ciudad tardomoderna o postmoderna, globalizada y multicultural, es donde el fenómeno del grafiti se manifiesta como una eclosión masiva, irrefrenable, permanente y fluida, gracias a un complejo plexo de condiciones sociales, económicas y culturales: en el mercado, resultan sumamente accesibles recursos gráficos como las latas de aerosol industrial o los rotuladores de marca; existen nuevos medios de reproducción 
técnica de la imagen, y se difunden rápidamente los mensajes y reproducciones a través de las redes descentradas de las nuevas tecnologías de la información y la comunicación; los espacios liminares y fracturas del orden social y urbano se multiplican, como consecuencia de la precarización laboral o de las nuevas formas de segregación y exclusión; además, asistimos a la fragmentación y redefinición constante de las identidades, las solidaridades y los relatos culturales, y se reestructuran los ámbitos de la intimidad, de la privacidad y de la publicidad, al mismo tiempo que resultan colonizados por la creciente mercantilización y sujeción a los códigos de la moda bajo el capitalismo de consumo contemporáneo; por último, vemos desplegarse nuevas demandas sociales y formas contraculturales que expresan variopintas estrategias de resistencia política y estética.

En la historia reciente, los usos de la inscripción urbana no responden a un único perfil, ya que los usos contestatarios y contraculturales del grafiti cohabitan frecuentemente con la reproducción del lenguaje del odio y las marcas excluyentes. Al fin y al cabo, no hay que olvidar que el partido nacionalsocialista alemán empleó estratégicamente la pintada mural como un instrumento de estigmatización en la primera fase del holocausto, es decir, en la identificación y marcado de la víctima judía. Ciertamente, también existen usos subversivos de la escritura de grafitis en el movimiento estudiantil francés de mayo del 68 o en los movimientos de izquierda latinoamericanos, que hicieron de la escritura mural un medio de agitación y propaganda. Sin embargo, el grafiti urbano contemporáneo no constituye 
automáticamente un medio de resistencia antisistema ni se identifica de modo obvio con la expresión autónoma de la iniciativa de los sectores populares excluidos; también se ha puesto al servicio del marcado territorial por parte de pandillas callejeras, que reproducen cierta subcultura machista de la violencia, eventualmente vinculada a formas ideológicas tan funcionales al sistema como el reconocimiento en el imaginario del deporteespectáculo de masas (tal y como ocurre en las barras bravas latinoamericanas y los hooligans europeos).

Actualmente, en los muros de una misma ciudad podemos encontrar pintadas de odio racial y eslóganes reaccionarios de ultraderecha, al lado de réplicas antifascistas, lemas anarquistas, logos animalistas o de reivindicación étnica, tags adolescentes, grafitis estilizados sin ninguna connotación política, y tachaduras de todo lo anterior. En todo caso, conviene no confundir la pintada, que representa mensajes textuales sin mayor estilización, y el grafiti de firma, que no tiene mayores pretensiones de articular algún mensaje y exhibe una marcada voluntad de estilo en la inscripción mural, aunque no parece gozar de la autoconciencia estética propia de una forma de arte (Reyes-Sánchez, 2012).

Ahora bien, la ambivalencia funcional del grafiti se traduce en que, dentro de una misma ciudad, podamos encontrar un tipo de grafiti localmente arraigado en algún barrio, que exprese endógenamente la integración comunitaria y territorial de sectores populares, así como la apropiación estética del entorno urbano, al margen de las intervenciones oficiales sobre la práctica o de la 
domesticación comercial del estilo. Sin embargo, también topamos con un tipo de grafiti exógeno y extraterritorial —normalmente en sectores de la ciudad con una vida subcultural y ambiente bohemio particulares-, que fomenta la exploración lúdica y la experimentación formal, los estilos transgresores y la innovación crítica, en el marco del escaparate cultural underground. Incluso, podríamos dar con otro tipo de grafiti instrumentalizado y perfectamente funcional a la institucionalización y comercialización de la inscripción urbana, que se limita a decorar por encargo locales, comercios o espacios urbanos, para lograr cierto ahorro en limpieza de pintadas descontroladas y conseguir una modernización estética aparente de las marcas, negocios y organismos públicos (Figueroa-Saavedra, 2007).

El grafiti contemporáneo no constituye un fenómeno homogéneo y compacto, ya que, desde los años sesenta hasta la actualidad, ha asumido muy diferentes formas y funciones. En efecto, el grafiti urbano ha dado lugar a todo un repertorio diversificado, en el que cabe reconocer cierta "historia natural" de este género de inscripciones. En un primer estadio, predominan la escritura lineal con aerosol, la reproducción masiva de nombres o sobrenombres y la multiplicación de firmas sin demasiada elaboración gráfica (como los conocidos tags de Taki 183 o Julio 204 en las calles de Nueva York).

En un segundo escenario - como consecuencia de la saturación creciente del medio por la difusión e imitación masivas del simple tag, y debido al creciente control y represión del fenómeno- se plantean presiones selectivas para un 
tipo de inscripción distintiva en lugares públicos visibles, y asistimos a la creciente sofisticación estilística de los diseños (con estilos nuevos de escritura como el bubble, de formas redondeadas, o los bloques yuxtapuestos del block) y repertorios cromáticos más variados; pero también se aprecia una cada vez más monumental dimensión de las firmas, que comienzan a perfilarse como auténticas realizaciones estéticas (pieces), aunque estén marcadas por la rapidez y oportunidad de la ejecución (como las firmas de los célebres escritores de grafiti de New York Super Kool 223, Phase II, Seen, Lee, Dondi o Blade, entre otros). Este estadio de creación de grafiti resulta inseparable del contexto social de las barriadas afroamericanas y latinas, de las pandillas callejeras y del movimiento contracultural del hip hop, que introdujo toda una estética y un abanico de apuestas estilísticas en el ámbito de la música, la danza, la vestimenta y, por supuesto, en la imaginería urbana y el estilo visual (Ferrell, 1993).

En el tercer estadio, el grafiti evoluciona hacia formas más reconocidas públicamente de creación artística, de modo que se impone la experimentación formal (con la tridimensionalidad, el color, la introducción de medios como las plantillas, y soportes como el cartel o las pegatinas), la ampliación de los motivos más allá de la caligrafía (figuración, abstracción, caricatura) y la diferenciación estética de estilos (el wild style, con sus laberínticas tramas, las figuras tridimensionales del model pastel, o los colores decadentes del dirty, etc.); pero también asistimos a la creación de colectivos creativos contraculturales, a la internacionalización del fenómeno, a la 
etnificación de algunos estilos y a la comunicación global entre los creadores. Actualmente, y desde los años noventa, estos diferentes estadios del grafiti coexisten en una extraña asincronía y se hacen presentes a través de todo el convulso y fracturado espacio público de las ciudades de todo el orbe.

Si bien existe un complejo entramado social e histórico que sobredetermina las formas y funciones del grafiti en la sociedad contemporánea, existe cierta especificidad semiótica en el modo de significación y en el tipo de lenguaje visual del grafiti de firma. Por una parte, el grafiti de firma introduce un icono-texto por antonomasia: funde el texto verbal y el lenguaje visual de tal manera, que neutraliza o deconstruye la clásica oposición entre mensajes icónicos y signos verbales. Hay todo un sistema de oposiciones que separan la imagen y la palabra: se suele contraponer la capacidad de identificación ostensiva de la imagen icónica y la modalidad de designación categorial o conceptual de la palabra; se contrasta la relación isomórfica o análoga de la imagen con lo representado y, por otra parte, la relación arbitraria e inmotivada entre el significante y el significado lingüístico; asimismo, se distingue la simple reproducción de la apariencia mediante imágenes, frente a la denominación lingüística convencional y abstracta (Gubern, 1987).

Sin embargo, el grafiti de firma constituye un tipo de texto intrínsecamente icónico que es, simultáneamente, la imagen estilizada de una nominación lingüística o, en ciertos casos, de un sobrenombre alfanumérico. En fin, el 
grafiti de firma es un icono-texto sin guion, un iconotexto en sentido pleno, "constituido por elementos pictóricos y verbales en ósmosis y amalgama recurrente" (Garí, 1995, p. 26). Aunado a lo anterior, el grafiti de firma desborda la retórica convencional de la imagen, tal como la concibió Roland Barthes (1986a); no en vano, este tipo de inscripción urbana incorpora simultáneamente dos formas concebibles de relación entre imagen y texto, esto es, el anclaje y fijación selectiva de las connotaciones de la imagen mediante el texto y, por otro lado, el relevo productivo e incitación recíproca entre imagen y texto, como ocurre en el cómic o en el cine.

Y es que el grafiti de firma entrecruza ambas modalidades funcionales - la fijación individualizadora de la imagen y la incitación estilizada de nuevas formas de inscripción imaginaria del lenguaje - hasta el punto de suspender cualquier viso de funcionalidad en la relación; finalmente, la transducción o transcodificación afuncional entre lenguaje e imagen $\multimap$ entre denotación ostensiva y connotación estética - parece imponerse como patrón de relación semiótica, que suspende cualquier pretensión de atribuir una significación calculable o un sentido naturalizado. Por lo demás, podría decirse que el grafiti introduce una relación suplementaria - un vínculo suspendido, o una intimidad dislocada y fuera de lugar - no solo entre texto e iconicidad, sino también entre caligrafía y alusión fugaz, entre el gesto y el signo, entre el trazado y el mensaje, entre el soporte y la inscripción (Barthes, 1986b). Como iconotexto por excelencia y sin guion, el grafiti de firma no es la imagen 
ilustrativa de un texto ni la articulación verbal de una apariencia icónica, sino un gesto suplementario con la materialidad del grafismo.

Hay otros sentidos en los cuales el grafiti de firma puede caracterizarse como un iconotexto sin guion: este tipo de inscripción urbana suele carecer de un marco oficialmente reconocido - hasta el punto de resultar criminalizado, ser prohibido y estar sujeto a persecución de la autoridad-; pero, además, desdibuja la línea de separación entre la dimensión interna de la práctica del grafffiti, la pragmática de su ejecución performativa o las lógicas inmanentes de su lenguaje subcultural y, por otra parte, los aspectos presuntamente externos de carácter político, sociológico o psicológico. En ese sentido, el grafiti de firma se perfila como un iconotexto sin guion en virtud de su condición indecidiblemente liminar y ambivalente.

Según ha argumentado Jeff Ferrell (1993), el grafiti puede ser considerado una expresión criminalizada de la experiencia de sectores juveniles socialmente excluidos a través de fronteras de clase y raza, y al mismo tiempo ser visto como una estética compartida de subculturas locales que, desde los márgenes del sistema y mediante la innovación estilística, resisten al control institucional y a la intolerancia del modelo económico y de la autoridad política. Desde ese punto de vista, el grafiti aúna la práctica estética con la historia subalterna, la desigualdad social y la inmediatez de la situación; involucra tanto los aspectos estilísticos como las identidades 
colectivas subculturales implicadas en la ejecución performativa de la inscripción urbana.

Así pues, —según Ferrell— cabe pensar que el grafiti es un delito estético o bien la realización del estilo como delito; incorpora una compleja dialéctica entre estructuras sociales, recursos estilísticos, prácticas estéticas y oportunidades o circunstancias de ejecución. En todo caso, los marcos de desigualdad social y dominación político-económica, que limitan el acceso a los recursos culturales y condicionan las formas de expresión estética, no determinan los cauces a veces sutiles a través de los cuales la inscripción urbana subvierte el imaginario público.

En la intersección entre el acto político, la performance artística y el estilo interpersonal, el grafiti se inscribe liminalmente en el espacio público como una revuelta estética o un modo de insubordinación estilístico, sin otro guion que la acción directa, solamente enmarcada por la excitación placentera al ejecutar un tipo de creación colectiva antagónica a la ley, la propiedad privada y el arte oficial. En fin, podríamos decir que el grafiti suspende los límites del control social y personal, de modo que sus prácticas de sabotaje estético se sitúan al margen de las rutinas cotidianas, fuera de los encuadramientos dispuestos por la autoridad y más allá de los lineamientos del imaginario colonizado y los estilos prefabricados del capitalismo de consumo. De ese modo, a través de una resistencia descentrada y de una revuelta creativa contra los marcos estéticos de la autoridad, el grafiti permitiría redefinir 
constantemente los límites del espacio público, del arte público y de los estilos colectivos (Ferrell, 1993).

Cuando examinamos el imaginario estético y los rituales performativos de la inscripción urbana, sus producciones y prácticas, se pone de manifiesto la condición liminar de ese iconotexto sin guion que es el grafiti de firma. Como plantea Rafael Schacter (2014), junto a los aspectos formales involucrados en la renovación del régimen visual urbano, el grafiti implica un profundo compromiso estético y ético con el cultivo de un arte público independiente, sin recompensa, aunque con riesgos y costes personales.

El grafiti entrelaza la extrañeza estética y la implicación práctica comprometida, la contemplación distanciada de la obra y la performance fronteriza y marginal. Además del disfrute de la acción directa concreta y de la actuación situacional en la esfera pública, la inscripción urbana parece introducir vínculos comunitarios no dependientes de fronteras locales, sino solo acotados por la práctica itinerante y el trabajo en redes cosmopolitas.

Así las cosas, el grafiti se asocia a una ambivalente labor de ornamentación y estilización del espacio público; aporta un recubrimiento decorativo de la suciedad y desorden urbanos, si bien dicha labor ornamental exhibe un doble talante posible, tan pronto consensual y legitimador, cuanto agonístico y transgresor. En ese sentido, la inscripción urbana explora los márgenes internos de la relación entre orden y ornamentación; es decir, se sitúa en el doblez entre la disposición adecuada de las estructuras y la decoración 
superficial de algunos ámbitos, y se hace cargo de la inestable exterioridad suplementaria que rige el nexo entre ordenación y ornamento. Según Schacter, el grafiti redefine los límites estructurales del orden público mediante la estilización ornamental extraterritorial y marginal, con propuestas de nuevas prácticas, imaginarios y códigos comunicativos consensuales libres de dominación, ajenos al control instrumental y a la mercantilización. Pero también ejecuta performativamente la impugnación transgresora del orden establecido, al articular el disenso y posibilitar la inscripción disruptiva de otros registros colectivos y la construcción de otras realidades sociales.

En suma, el grafiti pone de manifiesto cierta permeabilidad de las fronteras, a través de una práctica estético-política deconstructiva que tiene lugar en los límites entre lo público y lo privado, en los umbrales del espacio urbano; constituye una apuesta liminal marcada por la exterioridad y el trabajo estilístico en los márgenes, entre la cotidianeidad y lo estéticamente extraordinario, entre la banalidad diaria y el ritual creativo, pero también entre la inversión paródica y la subversión transgresora, o entre orden y ornamentación (Schacter, 2014).

Frente a cierta tendencia a idealizar la significación y la eficacia estéticopolíticos del grafiti, tal vez convenga recordar que las inscripciones urbanas pueden considerarse liminales también en la medida en que se asocian a ritos de iniciación subcultural y mecanismos de inclusión excluyente que reproducen a menudo esquemas hegemónicos del orden social. En ese sentido, Nancy 
Macdonald (2002) ha asumido el carácter ilegal del grafiti, en la medida en que la ejecución masiva y desordenada de pintadas no solo implica daño a la propiedad pública y privada, en desmedro de los presupuestos públicos y los impuestos de los contribuyentes; además, el grafiti acarrea riesgos personales innecesarios para quien realiza la inscripción.

Según Macdonald, el carácter liminal del grafiti no se puede atribuir únicamente a la voluntad de situarse al margen de la ley, romper con lo convencional y exponerse personalmente; también cabe relacionar la inscripción limítrofe del grafiti con cierto proceso de subjetivación y construcción de la identidad masculina, en virtud del cual el adolescente anónimo de género masculino, carente de posición y estatus, persigue encontrar un estilo propio, procura ganar reconocimiento y respeto, y reafirma cierto estereotipo de masculinidad que resulta inseparable de la exclusión de género.

Así pues, si nos situamos en el punto de vista del actor —en lugar de reproducir explicaciones relativas a la estructura del sistema socioeconómico, o en vez de jugar con interpretaciones deconstructivas de los sistemas sociosemióticos-, se ponen de manifiesto ciertos rendimientos liminales del grafiti, que conciernen a los procesos de cambio y transición desde una posición marginal en que el adolescente no es nadie, hasta la conquista de cierta posición como macho adulto, que consigue ser alguien al gozar de una membrecía subcultural. 
En suma, - para Macdonald - el carácter liminal del grafiti se asocia básicamente a determinado rito transicional o de pasaje, que implica aventurarse desde una posición excluida a otra de inclusión, mediante una dedicada práctica al margen de la ley. En ese sentido, la inscripción urbana operaría como un dispositivo identitario de incorporación en una subcultura de jóvenes machos, de manera que la performance del grafiti no deja de reproducir estereotipos de género, esto es, esquemas de inclusión excluyente funcionales a la construcción simbólica de la identidad. En todo caso, este proceso de subjetivación no es compacto, sino que involucra un complejo juego y negociación entre las múltiples identidades y roles que desempeña el adolescente en la vida cotidiana (Macdonald, 2002). De nuevo, el grafiti de firma se esboza como un iconotexto carente de guion.

Panofsky (1982) ha caracterizado la iconografía como un tipo de estudio de la imagen artística en el cual se analizan los distintos los estratos de significación separadamente: habría que describir el significado fáctico y expresivo de las formas y motivos representados; a continuación tendríamos que acceder a los significados convencionales que nos remiten a temas tradicionales o pautas temáticas históricas; finalmente se llevaría a cabo la interpretación iconológica que devela los valores simbólicos profundos, las cosmovisiones y comprensiones culturales de fondo.

Respecto a la descripción de las formas y motivos del grafiti, Regina Blume (1985) ha desarrollado un análisis discursivo de las principales funciones

\section{Un análisis iconográfico del grafiti de firma}


lingüísticas y de las dimensiones semánticas y pragmáticas de la inscripción urbana. En ese sentido, el grafiti se realiza habitualmente sobre soportes específicos disponibles en el paisaje urbano de las sociedades industriales, como los baños públicos, los vestuarios, las celdas, las estaciones, las salas de espera, los paraderos de autobuses, las cabinas telefónicas, los ascensores, los bancos y árboles de los parques, el mobiliario escolar, los monumentos, los edificios señeros, los muros perimétricos de las viviendas, los pilares de puentes, las señales de tráfico o el transporte público (Blume, 1985).

Los medios de inscripción privilegiados son la pintura de aerosol y los rotuladores gruesos, aunque en la ejecución de algunas formas de grafiti también se recurre a las pegatinas o a las plantillas. Si bien existen inscripciones urbanas que consisten en lemas o eslóganes, el grafiti de firma que estamos analizando consiste sintácticamente en sintagmas nominales suboracionales; suele tratarse de nombres propios o sobrenombres, muchas veces acortados como hipocorísticos, y también encontramos expresiones formadas mediante siglas, o bien términos alfanuméricos que añaden guarismos, ya sea como abreviatura fonética o como información de coordenadas espacio-temporales (direcciones y fechas).

Desde el punto de vista de las motivaciones implicadas en la inscripción urbana, Blume considera que el grafiti se asocia a ciertas funciones comunicativas, de modo que puede constituir una prueba de existencia, una respuesta a la necesidad de autoexpresión personal, una seña de membrecía 
grupal, una manifestación placentera de creatividad estética y un producto del aburrimiento; pero también se vincula a la protesta o el disentimiento, al marcado de territorio o a la búsqueda de contacto con otros (Blume, 1985). Por lo demás, podría considerarse que el grafiti de firma realiza también cierta función lingüística de autolocución poética —es decir, un mensaje autodirigido con referencias personales estilizadas, o la estilización de un acto discursivo tan identitario como ensimismado-, por cuanto inscribe anónimamente sobrenombres o apodos subculturales (a veces, múltiples tags) con características paródicas e imaginativas.

Desde el punto de vista formal, una primera apreciación del grafiti de firma nos permite sostener que estamos ante cierto ejercicio de caligrafía ornamental disruptiva: se trata de la inscripción de grafemas tan estilizados como distorsionados, o bien de la escritura idiosincrática de letras ornamentales atípicas, que se desvían de las tipografías textuales convencionales, para hacer posible el diseño de un logotipo paródico subcultural. Los recursos de esta caligrafía disruptiva son tan variados como los del arte tipográfico tradicional o los del moderno diseño de logotipos (Frutiger, 2007).

En algunos grafitis elementales, la deformación afecta básicamente al trazado de las letras (al enfatizar la forma lineal o dar curvatura a los trazos; o al modificar los ángulos, la inclinación de la letra, el cierre o apertura del patrón, etc.); también, se logra mediante la simplificación formal, mediante la 
expansión de las líneas en superficies, mediante el resaltado de volúmenes o las configuraciones tridimensionales (a veces con efectos cercanos a la anamorfosis). Podría decirse que la caligrafía ornamental del grafiti constituye una forma de cursiva por excelencia, debido a su carácter corriente o popular, a la rapidez de su ejecución y a la introducción de enlaces y bucles entre las letras (Haarmann, 2001); pero, además, despliega un tipo de letra intrínsecamente bastarda, que mezcla motivos formales de la textura gótica, diseños de tipo modernista, así como otros elementos estilísticos con resonancias futuristas, étnicas, cinéticas y pop.

Además de recurrir a la deformación e hibridación creativa de la letra, el grafiti también genera distorsión mediante el juego formal con el conjunto del segmento textual (al modificar los tamaños relativos de las letras y al magnificar el texto, al enlazar o solapar los segmentos, al entrelazar de modo complejo las líneas que conforman las letras, al disponer verticalmente el diseño, etc.). Con frecuencia los grafitis introducen trazos decorativos y elementos icónicos ornamentales como flechas, estrellas, burbujas, piezas mecánicas, flores, corazones, ojos, alas, etc. En los grafitis más elaborados juegan un papel fundamental la plasticidad del color y del sombreado, así como la reproducción de diferentes texturas (metalizadas, pastosas, líquidas, cristalizadas, etc.).

Con todo este repertorio de recursos ornamentales se introducen aspectos figurativos que evocan formas orgánicas, embrolladas tramas cortantes, 
bloques inamovibles, dispositivos mecánicos disfuncionales, juegos de construcción o configuraciones arquitectónicas imposibles. En fin, el grafiti de firma constituye un particular tipo de iconotexto que aúna la inscripción textual y la representación figurativa, la designación rígida y la iconicidad de la estilización (o la ornamentación caligráfica del lenguaje). De ese modo, este tipo de inscripción urbana se configura como un pictograma o ideograma (en rigor, un "idiograma") subcultural en el que se confunden plenamente la forma y el sentido, el texto y la imagen, la opacidad semántica y la exuberancia plástica.

Así como el cifrado de la identidad y la autoexpresión anónima son motivos característicos del grafiti de firma, también la forma de su escritura responde a cierta semiótica del encubrimiento y de lo indescifrable; por eso, no son extraños los patrones alfanuméricos, los diseños laberínticos o el arabesco formal, que finalmente hacen ilegible el texto, pero le brindan autonomía estética al diseño y confirman el carácter icónico y alusivo de la inscripción.

Al explorar las temáticas tradicionales y convenciones culturales con que se asocia el grafiti de firma, podemos reconocer su parentesco con símbolos de identificación (marcas, blasones, firmas, logotipos, etc.) que, a través de la historia, han proporcionado medios semióticos para significar la singularidad de una persona o asociar al individuo con su grupo de referencia e, incluso, con su propiedad o producto (Haarmann, 2001). Podríamos designar como icononimia (o, también, idiografía) a este tipo de simbolismo gráfico que lleva 
a cabo una nominación icónica e implica una operación semiótica de identificación a través de formas figurativas más o menos abstractas y convencionales.

Una primera forma de icononimia se encuentra en la signatura individual que permite singularizar a una persona concreta. Las signaturas individuales se han utilizado como marcas distintivas a través de la historia, ya sea bajo la forma de un signo de propiedad o autoría (como las signaturas medievales de los canteros y los gremios de la construcción) o bien con las características de la firma rubricada, que autentifica la identidad personal del sujeto enunciativo en una sociedad letrada.

También existe una forma de icononimia ligada a los sellos y monogramas que -en nuestra tradición histórica- designan simbólicamente a un individuo de las clases dominantes o dirigentes, mediante una disposición gráfica de combinaciones de letras y elementos icónicos (como coronas y cruces) (Frutiger, 2007). Del mismo modo, reconocemos un fenómeno de icononimia en los signos familiares (divisas, blasones, enseñas y escudos) que singularizan a una determinada casa o linaje; todo este universo simbólico de la heráldica está sujeto a cierta codificación convencional de las formas, colores y motivos, pero también exhibe claros indicios de motivación semiótica al suponer frecuentemente una relación figurativa o analógica entre el apellido de la casa y los elementos representados en su signo familiar. 
En la modernidad encontramos signos de identificación comunitaria que simbolizan gráficamente la pertenencia política o la adhesión personal a ciertos movimientos u organizaciones sociales (como ocurre en los logotipos estilizados de los partidos políticos, los sindicatos y diferentes asociaciones y organizaciones). Por supuesto, en una sociedad como la moderna formación social capitalista, configurada por las interacciones en un mercado presuntamente autorregulado — esto es, caracterizada por la primacía de las relaciones con cosas y mercancías, que imperan sobre las relaciones interpersonales - no es de extrañar que las marcas se hayan convertido en un signo de identificación crucial, que permite individualizar al propietario, al profesional o al productor; en ese sentido, las marcas, logotipos y firmas mercantiles introducen una forma de icononimia que oscila entre la abstracción formal y la naturalización figurativa (Frutiger, 2007).

El grafiti guarda un parentesco con expresiones de icononimia como las signaturas, las enseñas o las marcas, pero también exhibe algunas diferencias con esos otros procedimientos semióticos de nominación icónica. Como las signaturas individuales, el grafiti de firma realiza un acto performativo de identificación y singularización, en el cual resulta central la nominación y la inscripción textual de grafemas o letras. Sin embargo, este tipo de inscripción urbana no pretende registrar la autoría o propiedad, ni autentificar o autorizar ante la ley, sino que solo parece explorar estilísticamente el cifrado de la subjetividad y la autoexpresión estética al margen de la ley. 
Así pues, el grafiti es más exuberante desde el punto de vista plástico y estilístico, que las signaturas individuales o las firmas personales. Como las enseñas y blasones, el grafiti sostiene cierta identificación grupal a través de un símbolo gráfico que guarda algún tipo de relación analógica con un nombre, y puede introducir elementos figurativos con significados simbólicos más o menos convencionales. No obstante, en la heráldica predomina el elemento icónico y la simbolización convencional, por sobre la nominación; como contrapartida, el grafiti de firma suele incorporar los segmentos textuales o sintagmas lingüísticos de nombres y sobrenombres (en algunos casos, expresiones alfanuméricas).

Como las marcas y logotipos, el grafiti de firma constituye un diseño gráfico estilizado que incorpora frecuentemente segmentos textuales; sin embargo, la operación de identificación ejercida performativamente en la inscripción urbana no resulta instrumental a la exhibición o señalización de la mercancía, ni se subordina funcionalmente a la necesidad de aportar garantías en el curso del intercambio comercial, sino que privilegia la autoexploración estética del creador y la interacción simbólica que sostiene su pertenencia a grupos subculturales. Por cierto, el grafiti también se puede comparar con un tipo de signo de identificación propio de las redes socio-técnicas, constituidas gracias a los nuevos medios de información y comunicación, a saber: los nicknames empleados en foros, chats y otras plataformas de Internet. 
En las formas de comunicación computacionalmente mediadas, las personas suelen escoger sobrenombres y nombres ficticios - frecuentemente alfanuméricos-, que les permiten forjar una identidad alternativa y encubrir imaginariamente las limitaciones de la identidad cotidiana en el rutinario mundo real. En ese sentido, el nickname sintetiza lúdicamente en un texto imaginativo la identidad pretendida con que el internauta se autopresenta en la red, ya se trate de sobrenombres referidos a personajes legendarios de juegos, películas o series, o bien de nombres de gente famosa, de sobrenombres que reproducen alguna característica personal o interpersonal, incluidas la edad y procedencia, de apodos relacionados con el medio tecnológico, de expresiones provocativas, o bien de sobrenombres alusivos que juegan con el anonimato o cifran la subjetividad con todo tipo de juegos gráficos (Bechar-Israeli, 1995).

Como el nickname, el grafiti constituye un tipo de juego estilizado de autonominación cifrada y autoidentificación imaginaria a través de una signatura estilizada; asimismo, se vincula a la inclusión simbólica en comunidades de pares y a la interacción simbólica en ceremonias de iniciación identitaria basadas en cierta performance. Sin embargo, el elemento icónico, la exuberancia plástica y los recursos figurativos son mucho más decisivos en el grafiti que en el empleo de nicknames en la Red; además, la dimensión gestual, encarnada y situada de la performance creadora del grafiti no se hace presente en la comunicación computacionalmente mediada. 
No parece evidente que un tipo de imagen estéticamente motivada tan liminal y ambivalente como el grafiti de firma tenga un trasfondo simbólico inteligible. Si intentamos realizar una interpretación iconológica de sus dimensiones simbólicas de fondo, resultaría pertinente establecer el parentesco entre el grafiti y el muy humano placer de jugar por jugar, que ha tenido una indiscutible función civilizatoria y contribuyó decisivamente al cultivo del deleite estético con un arte autónomo.

Al reflexionar sobre el placentero juego de dibujar garabatos cuando se está aburrido con alguna tarea rutinaria, Ernst Gombrich (2003) alude a una doble relación entre el juego de garabatear y el arte reconocido: así como los garabatos suelen incorporar rasgos y convenciones estilísticas de los códigos del arte reconocido, también ocurre que la práctica artística puede verse influida por el relajado juego creador del garabato incidental (Gombrich, 2003). No en vano, el garabato permite explorar diseños geométricos u ornamentales que aparecen creativamente a través de la gestualidad autónoma de la mano.

Ahora bien, — según Gombrich — solo a partir de cierto momento de la historia del arte se privilegió la originalidad creativa y la expresión espontánea, por sobre el oficio aprendido y la destreza técnica del pintor; únicamente entonces, el garabato y el dibujo automático resultaron aceptables en los lenguajes del arte, como se aprecia en el Dadaísmo o el Surrealismo. Por lo demás, Gombrich establece un paralelismo explícito entre el garabato

\section{El trasfondo iconológico del grafiti de firma}


y el grafiti, en la medida en que ambos serían diseños circunstanciales; aunque el garabato solo responde al ensimismamiento privado, al juego evasivo y a la relajación del aburrimiento, mientras que el grafiti implicaría un acto de desfiguración de espacios públicos, una reivindicación de poder y un gesto agresivo (Gombrich, 2003).

En todo caso, el reconocimiento y cultivo del grafiti de firma como una manifestación estética autónoma solo resulta comprensible en el mismo trasfondo simbólico y cosmovisión cultural que hizo posible la inclusión del garabato gestual en el arte, a saber: la absolutización de la autonomía del arte y de la valoración estética, hasta ese punto en que se suspenden las coordenadas simbólicas y funciones socio-históricas del lenguaje artístico, se cuestionan los oficios, rituales e instituciones oficiales del arte tradicional, y finalmente asistimos a la deriva postaurática de un arte tan desencantado como masivo, superficial y de choque (Benjamin, 1989). También en ese sentido, el grafiti encarna un iconotexto sin guion, ya que se ejecuta al margen de un marco comprehensivo que aporte las coordenadas y valores simbólicos para la apreciación estética.

Aunque carezca de un marco estético comprehensivo, podría discutirse si acaso el grafiti no tiene valores simbólicos precisos. Jean Baudrillard (1980) ha defendido precisamente que el grafiti tiene una marcada carga simbólica, en la medida en que constituye un ritual simbólico de iniciación e intercambio colectivo intenso, tan vinculante como transgresor, tan grupal como anónimo. 
En ese sentido, el grafiti llevaría a cabo una rebelión simbólica contra el orden codificado de los signos, la distribución parcelada de las diferencias significativas y la conmutabilidad de los significantes, que liquidan la sustancia simbólica de lo social en la matriz urbana del capitalismo de consumo.

Si el ordenamiento urbano del capitalismo de consumo se sostiene en la circulación de los signos, en la reproducción programada del código y en la simulación de significantes conmutables, — según Baudrillard - el grafiti introduciría en la ciudad una revuelta simbólica mediante el anti-discurso de explosivo de todo un repertorio de signos irreferentes, significantes vacíos sin contenido ni mensaje-, que están más cerca de la interjección, de la nominación simbólica grupal y de la inscripción territorial.

De ese modo, la diferencia absoluta de los signos insurrectos desmantelaría el orden urbano de la diferencia codificada, desbordaría los marcos delimitadores de la ciudad, e imposibilitaría cualquier intento de reducción estética o ideológica, por tratarse de un fenómeno transestético y transideológico, que impugna subversivamente la economía política de los signos (Baudrillard, 1980). Posteriormente, Baudrillard (1993) consideró que en la sociedad contemporánea ya no regiría esa fase estructural del valor, en que los signos se distribuyen y conmutan en el orden del código; actualmente, regiría una fase fractal o viral del valor, en que los signos se vuelven irreferentes por su dispersión indiferente e interactiva, a través de la 
circulación mediática y operacional de simulacros, así como mediante la simulación hiperrealista que liquida definitivamente lo social.

Para Baudrillard, en esa revolución contemporánea de la incertidumbre y del vértigo, la utopía estética modernista (lograr la conciliación del arte con la vida, bajo la guía de alguna vanguardia revolucionaria) se consuma paradójicamente con el simulacro de una infraestetización general de la vida cotidiana —incluidas las anticulturales—, más allá de cualquier regla de juego o coordenada de juicio estético: como una transestética de la banalidad (Baudrillard, 1993). Desde ese punto de vista, cabría preguntarse si acaso el grafiti puede seguir siendo considerado como una insurrección simbólica, o nos encontramos con otra figura - quizá el reverso desbocado- de la banalización transestética de la imagen, que simplemente replica el modelo viral de reproducción indiferente de los signos vaciados de contenido.

Pese a que el grafiti de firma podría desafiar su inscripción en un orden simbólico comprehensivo o en un marco definido de categorías estéticas, encontramos interpretaciones que sugieren su participación en cierto horizonte común de gusto o mentalidad cultural. En ese sentido, Omar Calabrese (1999) ha defendido que existe una determinada atmósfera cultural contemporánea que podría designarse como "neobarroco"; se trata de un trasfondo intelectual y una estética social que valora la exploración formal, la desmesura, la mutabilidad, la excentricidad, la complejidad, la 
indeterminación, lo fragmentario, lo anómalo y lo aleatorio, en desmedro de la totalización de conjunto o el orden sistemático.

Precisamente, — según Calabrese - el grafiti encarna este universo estético de la indefinición, la imprecisión y la indefinición neobarroca, en la medida en que propone figuras frecuentemente indescifrables, inseparables de su fondo o superficie de ejecución y de la efímera duración temporal de su inscripción performativa y apreciación pasajera. No en vano, la inscripción urbana de firmas estilizadas tan solo enuncia confusamente cierto discurso borroso, carente de proyección y conexión sintáctica, así como semánticamente opaco y estilísticamente embrollado e impreciso; asimismo, la recepción del grafiti resulta vaga, indefinida e indiferente. En fin, - para Calabrese- el grafiti de firma, performativamente realizado como un repertorio de inscripciones urbanas incidentales y ambientales, responde a cierta estética de la velocidad, la imprecisión y el riesgo, que sería también la estética neobarroca alusiva del más-o-menos y del no-sé-qué (Calabrese, 1999).

Desde otra perspectiva, la interpretación del trasfondo simbólico del grafiti presupone que el escenario cultural contemporáneo se caracteriza - como sostiene Néstor García-Canclini (1990) — por una marcada hibridación, mestizaje y heterogeneidad sincrónica, en virtud de la cual se deconstruyen y neutralizan las oposiciones entre lo tradicional y lo moderno, o entre lo culto, lo popular y lo masivo. En efecto, — según García-Canclini- los procesos de 
modernización y posmodernización de los mercados simbólicos involucran cierta redefinición de los papeles del arte culto, del folclore popular y de la industria cultural de masas: la lógica del mercado, la industrialización de los mercados simbólicos, así como la mediatización cultural bajo los nuevos medios de comunicación y tecnologías de la información, nivelan el quehacer de artistas y artesanos, al mismo tiempo que desdibujan las pretensiones de autonomía simbólica de lo culto, lo popular y lo masivo.

Particularmente en la periferia, la relación entre tradición, modernismo cultural y modernización socioeconómica resulta sumamente compleja, inestable y de desarrollo desigual, de manera que - en regiones como América Latina - puede reconocerse una anticipación de la cultura del pastiche, del relativismo y del bricolage típicamente posmodernos. Por otra parte, - según García-Canclini- la hibridación cultural posmoderna resulta inseparable de cierta transnacionalización del mercado simbólico, acelerada por las tecnologías comunicacionales, los flujos demográficos y el turismo de masas, que tienen como consecuencia una reestructuración de las identidades nacionales, populares y personales.

En ese contexto de hibridación cultural, el grafiti expresaría determinada forma de crítica popular al orden simbólico hegemónico; se trata de un ejercicio mestizo e impuro, carente de paradigmas estéticos consistentes y de referentes de legitimidad, sin libreto ni autor públicamente reconocido, que cruza estilos muy diversos y diferentes técnicas culturales. Para García- 
Un iconotexto liminar. Análisis iconológico de los...

Canclini, el grafiti es un género constitutivamente híbrido, sincrético y transcultural, que cruza - a veces de modo indescifrable - lo visual y lo textual, la palabra y la imagen, y genera una inscripción urbana territorial no coleccionable como arte patrimonial. Además, estamos ante un tipo de icontexto con un talante liminal y marginal, que afirma provocativamente su estilo, e impugna el trazado preciso de los logos de la sociedad de consumo y los leguajes institucionales; de ese modo, se desestructura micropolíticamente el orden simbólico de la ciudad, y se desestabilizan las relaciones entre lo privado y lo público, en respuesta a la propia desregulación de los espacios urbanos (García-Canclini, 1990). En fin, el grafiti de firma se perfila como un icontexto liminar y sin guion, precisamente porque participa del trasfondo simbólico de un orden cultural cada vez más transnacionalizado e híbrido. 
Barthes, R. (1986a). Retórica de la imagen. En Lo obvio y lo obtuso. Imágenes, Referencias gestos, voces (pp. 29-48). Barcelona: Paidós.

Barthes, R. (1986b). Cy Twombly o Non multa sed multum. En Lo obvio y lo obtuso. Imágenes, gestos, voces (pp. 161-180). Barcelona: Paidós.

Baudrillard, J. (1993). La transparencia del mal. Ensayo sobre los fenómenos extremos. Barcelona: Anagrama.

Baudrillard, J. (1980). Kool Killer o la insurrección del signo. En El intercambio simbólico y la muerte (pp. 90-100). Caracas: Monte Ávila.

Bechar-Israeli, H. (1995). From 〈Bonehead〉 to 〈cLoNehEAd〉: nicknames, play, and identity on internet relay chat. Journal of Computer-Mediated Communication, 1(2).

Benjamin, W. (1989). La obra de arte en la época de su reproductibilidad técnica. En Discursos interrumpidos I (pp. 15-57). Buenos Aires: Taurus.

Blume, R. (1985). Graffiti. En T. A. van Dijk. (Ed.), Discourse and literatura (pp. 137-148). Philadelphia: John Benjamins Publishing Company.

Calabrese, O. (1999). La era neobarroca. Madrid: Cátedra.

Ferrell, J. (1993). Crimes of Syle. Urban Graffiti and the Politics of Criminality. Boston: Northeastern University Press.

Figueroa-Saavedra, F. (2007). Estética popular y espacio urbano: El papel del graffiti, la gráfica y las intervenciones de calle en la configuración de la 
Un iconotexto liminar. Análisis iconológico de los...

personalidad de barrio. Revista de Dialectología y Tradiciones Populares, 7(1), 111-144.

Frutiger, A. (2007). Signos, símbolos, marcas, señales. Barcelona: Gustavo Gili.

García-Canclini, N. (1990). Culturas híbridas. Estrategias para entrar y salir de la modernidad. México, D.F.: Grijalbo.

Garí, J. (1995). La conversación mural: Ensayo para una lectura del graffiti. Madrid: Fundesco.

Gombrich, E. H. (2003). Los placeres del aburrimiento. Cuatro siglos de garabatos. En Los usos de las imágenes. Estudios sobre la función social del arte y la comunicación visual (pp. 212-225). México, D. F.: Fondo de Cultura Económica.

Gubern, R. (1987). La mirada opulenta. Exploración de la iconosfera contemporánea. Barcelona: Gustavo Gili.

Haarmann, H. (2001). Historia universal de la escritura. Madrid: Gredos.

Macdonald, N. (2002). The graffiti subculture: youth, masculinity, and identity in London and New York. New York: Palgrave Macmillan.

Panofsky, E. (1982). Estudios sobre iconología. Madrid: Alianza Editorial.

Reyes-Sánchez, F. (2012). Graffiti. ¿Arte o vandalismo? Pensar la Publicidad, 6, 53-70. 
Schacter, R. (2014). Ornament and Order. Graffiti, Street and the Parergon. Surrey: Ashgate Publishing.

\section{¿Cómo citar este artículo?}

González de Requena Farré, N. (Enero-junio, 2017). Un iconotexto liminar. Análisis iconológico de los grafiti de firma. Revista humanidades, 7(1), 1-34. doi: http://dx.doi.org/10.15517/h.v7i1.27623 